6

Humanitarian

Situation in

Afghanistan

and on its

borders

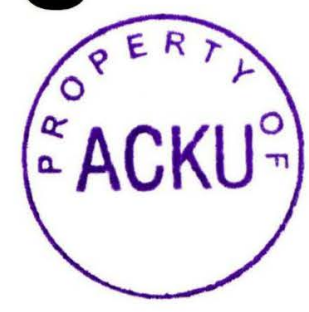

27 September 2001

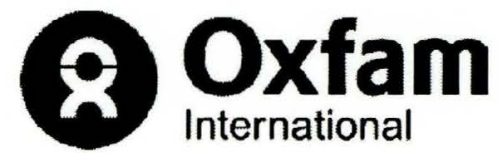




\section{Key concern}

Anticipation of a military strike on Afghanistan has prompted massive internal displacement of the population from urban areas. As of 27 September, with many heading for the closed borders, a humanitarian crisis is rapidly escalating.

Afghanistan is the poorest country in Asia. Even before the terrorist attacks on the USA on 11 September, it faced a winter of severe food shortages, leaving five million people at risk. This was caused by a combination of three years of successively worsening drought, and the continuing war between the Taliban and opposition United Front, based in the north. According to the UN, the figure of those needing assistance could rise to 7.5 million if the worst predictions are realized.

After suspending food deliveries for security reasons, the UN World Food Programme (WFP) will resume deliveries to selected parts of the country, principally in the north and west from Turkmenistan and Tajikistan. This still leaves many local systems for the distribution of food threatened with collapse before winter closes in, and consequently the likelihood of widespread starvation. The vital need to reach people by November cannot be overstated.

Problems for aid agencies entrusted with the distribution of food have been compounded by the decision of the Taliban authorities to ban all means of communication with the outside world. The Taliban is also reported to have seized 1400 tonnes of WFP food in Kandahar. So far there are no reports of other incidents of this nature and, faced with such overwhelming need, Oxfam's experienced team of local staff will continue to distribute food to carefully selected beneficiaries as long as conditions and supplies allow.

The UN is preparing to meet both present and anticipated need within Afghanistan and on its borders and has launched today an appeal for $\$ 582$ million dollars, which includes $\$ 273$ million for refugee assistance.

\section{Key messages}

- Sufficient stocks of food must reach both Taliban and opposition held areas of Afghanistan before the onset of winter.

Preparations should be made now to anticipate future need, including building up stockpiles and exploring other delivery options. In view of the huge tonnage that needs to be shifted, restarting trucking is clearly the best option, but contingency plans for airlifts should be made in case other alternatives prove impossible. 
- International borders should be opened immediately, allowing people to reach essential food and services.

- Camps should be prepared to ensure safe and adequate conditions for refugees in full accordance with the 1951 Refugee Convention and Sphere standards. ${ }^{1}$ Attention should be given to the specific needs of women in these camps.

- As the USA and its allies decide what action to take in Afghanistan, the humanitarian consequences of any action must be carefully calculated and prepared for. They must protect the lives of civilians, and seek to reduce the fear driving displacement by avoiding all civilian targets or military targets dangerously close to concentrations of civilians in either urban settlements or camps for internally displaced people.

- The aim to minimize the level of human suffering in Afghanistan demands a generous response: a humanitarian coalition of donors must back the UN appeal to ensure sufficient funds are available to meet these needs. The allocation must be new money and not diverted from budgets for other areas of the world.

- Our appeal to protect civilian lives applies equally to the Taliban. We join with UN agencies in the call to the Taliban authorities to facilitate the delivery of humanitarian supplies to civilians in need, including allowing aid agencies access to communication facilities for both logistical and delivery verification processes.

\section{There are three main problems over the next six months:}

1 Although access to information is very poor, recent significant population movements of an estimated 170,000 towards Pakistan, as well as other internal displacements of an estimated one million people, could increase vulnerability to malnutrition and disease. These displacements present new challenges for aid agencies seeking to bring relief supplies across closed borders.

2 In anticipation of Pakistan's border being re-opened, preparations should be made now to ensure that the capacity of camps around Peshawar and Quetta, whose standards are already poor or uncertain, are not overwhelmed. At UNHCR's request, Oxfam is leading urgent contingency planning for water and sanitation support within Pakistan.

3 Tens of thousands of deaths could result from starvation throughout Afghanistan if WFP is unable to provide sufficient

\footnotetext{
${ }^{1}$ Minimum standards agreed by humanitarian agencies for sustaining the lives and dignity of those affected by calamity and conflict.
} 
supplies for distribution before access is constrained by the onset of winter snows at the end of November. Oxfam welcomes WFP's decision to restart supplies in some areas of Afghanistan, but unless access and communication issues are resolved to all regions, many people will remain out of reach.

\section{Current humanitarian situation}

'We all know we don't have enough food for winter, even in town. Some people know that if this situation continues they will not survive'

Oxfam worker, September 2001

The 2001 harvest has been about 50 per cent that of a normal year (much lower in some regions), in the third year of a severe drought. Before recent events, this was already leaving five million people around 20 per cent of the population - at risk of severe food shortages.

Relief supplies are needed now. In August it was estimated that 400,000 would run out of food by the end of September, with an additional 1.4 million by the end of this year. With the large internal population movements currently seen, the disruption of food assistance and trade, a situation is rapidly developing in which thousands could die.

In the event of a military strike on Afghanistan, the UN estimates that about 1.5 million people will attempt to cross into bordering countries, with a further 2.2 million people displaced within the country. Approximately a further 4 million remaining in their homes will also need assistance.

\section{Women}

The humanitarian crisis in Afghanistan will fall heaviest on the most vulnerable sections of the population. Women are faced by particular stresses. Before this crisis began, the gender disparity in Afghanistan, based on life expectancy, education and income, was already the widest in the world. Only 15 per cent of women (compared to 47 per cent of men) are literate; women are not allowed to work outside the home, except in the health sector, or attend school. Families' ability to cope with times of crisis is severely restricted by the limits on women's ability to work. There are also around one million war widows who have no option but to be dependent on their extended families or beg. Restrictions on women's freedom of movement raise concerns about their ability to access food. For those women who reach refugee camps, their specific needs, including physical security, must be properly accommodated. 


\section{Refugee populations in neighbouring countries}

\section{Pakistan}

Little information exists about the numbers of people moving towards the borders, but it is thought that some of the largest movements are out of the Taliban strongholds of Kandahar and Kabul towards the border with Pakistan.

Before the present crisis, Pakistan was already host to around two million Afghan refugees, one of the highest ratios of refugee to host populations in the world (1:75). The UN estimates that figure could rise by a further million in the event of military action. The UN has appealed to all of Afghanistan's neighbours to open their borders, but for the moment the Pakistan authorities have decided to keep their border closed.

The Pakistan government is in the process of identifying some 70 camps around Quetta and Peshawar for the reception of refugees. It is vital that they are made fit to receive large numbers of people. Priority should be placed on ensuring that arrangements in camps reach internationally recognized Sphere standards. To this end, all arrivals must be properly screened to ensure the civilian nature of the camps. Issues of access and security must be resolved. Technical aspects, such as water provision in a drought-affected area, must be fully considered.

Oxfam is working with the UNHCR to provide water engineering advice for the identification of suitable sites for camps. Special efforts are being made to ensure that water can be delivered to women and other vulnerable groups. Contingency planning for a refugee influx is underway in both Pakistan and Iran.

\section{Iran}

Iran hosts around 1.4 million Afghan refugees, mostly dispersed throughout the population. It has closed its border with its neighbour but has identified seven camps on the Afghan side for the reception of internally displaced people, five bordering Khorasan province and two bordering Baluchestan province. The UN anticipates that around 400,000 people may head for this border in the event of a military strike. Iran has called on international relief organizations to help provide assistance. Screening, security, access and provision of decent living conditions must be a priority in the establishment of these camps.

Oxfam is exploring the possibility of working with partners in Iran to provide assistance in public and environmental health to these refugees. 


\section{The North}

The borders with Afghanistan's northern neighbours - Uzbekistan, Turkmenistan and Tajikistan - remain closed, though deliveries of relief supplies will resume through the latter two countries. In the event of military activity intensifying in the northern regions of Afghanistan, the UN believes that around 100,000 may seek to cross these borders.

There are risks from any increased Taliban-United Front fighting of population movements, particularly from Baluchistan, towards northern neighbours. This may cause severe strain, as all central Asian states are also affected by the three-year drought, most severely in the southern Khation and northern Leninabad regions of Tajikistan, and the Karakalpakistan region of Uzbekistan.

\section{Within Afghanistan}

The people fleeing for safety are those who can afford to make the journey to the border; many of the most vulnerable remain to seek what shelter they can find. If the UN estimates prove correct, the vast majority of those in need - some six million people - will be those left behind in Afghanistan.

The outlook in some of the most vulnerable regions is as follows.

\section{Badakhshan}

- This region, not under Taliban control, is unable to produce adequate food in any year. The 2001 harvest has been negligible. However, whilst this is one of the areas facing the acutest food shortages, it may also one of the regions to benefit from the resumption of WFP deliveries.

\section{Balkh}

- There are reports of renewed fighting in this region as as the Northern Alliance claim to have taken Zari Province from the Taliban.

- On 21 September, Oxfam succeeded in getting 1500 tonnes of food aid from Uzbekistan into a camp for the homeless in MazarI-Sharif. This however is only a drop in the ocean compared to the level of need in the region.

\section{Hazarajat}

- The latest food distribution will cover needs until mid-October in the four drought-affected districts. Locally harvested food may enable people to remain where they are located beyond this, perhaps to mid-November. 
- Further distribution of food must take place before the end of November, after which the region will be cut off by winter conditions until April 2002.

- Although the population in the main valleys should be able to survive, there is likely to be widespread malnutrition, with significant death rates, in the sub-valleys if people are unable to move to find food.

\section{Herat region}

\section{Jawand}

- Oxfam and others' food stocks are sufficient until approximately early November, although distribution is always threatened by intermittent fighting.

- If WFP is unable to restock food by November, there are likely to be major population movements to camps for internally displaced people in Herat.

- If those camps are not restocked with food, this displacement could lead to significant rioting which would compound widespread starvation.

- The last food distribution will cover needs until mid-October. Otherwise, the situation is similar to that in Jawand, with likely displacement towards Herat, with the Turkmenistan border closed.

\section{Kandahar}

\section{Zabul}

- Although there has been no food distribution since August, and WFP stocks will be quickly exhausted if not re-supplied from outside Afghanistan, there is likely to be more access to local fruit and nut crops than in other regions.

\section{Oxfam's programme}

Oxfam International's programme is less dependent on international staff than most other agencies in Afghanistan, and it continues where conditions allow with much of its work reaching approximately 750,000 people. Humanitarian programmes are continuing in Hazarajat, Herat and Badakshan, principally food assistance, but also seed supply, water supply and infrastructure rehabilitation.

However, its food distributions, whether implemented directly by Oxfam or by local partners, will be severely constrained without WFP 
re-supply from outside the country before the winter and without communications with its local staff.

Oxfam has been working in Pakistan since 1973. It has responded to past emergencies, including floods in 1992 and 1995, cyclone in 1999 and drought response in 200 and 2001.

Click here for a map of Afghanistan:

http://www.un.org/Depts/Cartographic/map/profile/afghanis.pd f 
Oxfam International is a confederation of twelve development agencies that work in 120 countries throughout the developing world: Oxfam America, Oxfam in Belgium, Oxfam Canada, Oxfam Community Aid Abroad (Australia), Oxfam Great Britain, Oxfam Hong Kong, Intermon Oxfam (Spain), Oxfam Ireland, Novib, Oxfam New Zealand, and Oxfam Quebec. Please call or write to any of the agencies for further information.

Oxfam International Advocacy Office, 111216 th St., NW, Ste. 600, Washington, DC 20036 Phone 1.202.496.1170, Fax 1.202.496.0128, E-mail: advocacy@oxfaminternational.org, www.oxfam.org

Oxfam Germany

Greifswalder Str. 33a

10405 Berlin, Germany

+493042850621(ph)

E-mail: info@oxfam.de www.oxfam.de

\section{Oxfam-in-Belgium}

Rue des Quatre Vents 60

1080 Burxelles, Belgium

32.2.501.6700 (ph)

E-mail: oxfamsol@oxfamsol.be www.oxfamsol.be

Oxfam Community Aid Abroad

National \& Victorian Offices

156 George St. (Corner Webb Street)

Fitzroy, Victoria, Australia 3065

61.3.9289.9444 (ph)

E-mail: enquire@caa.org.au

www.caa.org.au

\section{Oxfam GB}

274 Banbury Road, Oxford

England OX2 7DZ

44.1865.311.311 (ph)

E-mail: oxfam@oxfam.org.uk

www.oxfam.org.uk

\section{Oxfam New Zealand}

Level 1, 62 Aitken Terrace

Kingsland, Auckland

New Zealand

PO Box for all Mail: PO Box 68357

Auckland 1032

New Zealand

64.9.358.180 (ph)

E-mail: oxfam@oxfam.org.nz

www.oxfam.org.nz

Intermon Oxfam

Roger de Lluria 15 08010, Barcelona, Spain

34.3.482.0700 (ph)

E-mail: intermon@intermon.org

www.intermon.org
Oxfam America

26 West St.

Boston, MA 02111-1206

1.617.482.1211 (ph)

E-mail: info@oxfamamerica.org www.oxfamamerica.org

Oxfam Canada

Suite 300-294 Albert St.

Ottawa, Ontario, Canada K1P 6E6

1.613.237.5236 (ph)

E-mail: enquire@oxfam.ca

www.oxfam.ca

Oxfam Hong Kong

$17 / F$, China United Centre

28 Marble Road, North Point

Hong Kong

852.2520.2525 (ph)

E-Mail: info@oxfam.org.hk

www.oxfam.org.hk

Oxfam Quebec

2330 rue Notre-Dame Quest

Bureau 200, Montreal, Quebec

Canada H3J 2 Y2

1.514.937.1614 (ph)

E-mail: info@oxfam.qc.ca

uww.oxfam.qc.ca

Oxfam Ireland

Dublin Office:

9 Burgh Quay, Dublin 2, Ireland

353.1.672.7662 (ph)

E-mail: oxireland@oxfam.ie

Belfast Office:

52-54 Dublin Road, Belfast BT2 7HN

44.289.0023.0220 (ph)

E-mail: oxfam@oxfamni.org.uk

www.oxfamireland.org

Novib

Mauritskade 9

2514 HD. The Hague, The Netherlands

31.70.342.1621 (ph)

E-mail: info@novib.nl

www.novib.nl 